\title{
PHYTOCHEMICAL CONSTITUENTS, ANTIOXIDANT, ANTIBACTERIAL AND ENZYME INHIBITION ACTIVITIES OF ESSENTIAL OIL FROM THE AERIAL PART OF Achillea tomentosa L. GROWN IN JORDAN
}

\author{
SOHAIL AHMAD ALSOHAILI ${ }^{a^{*}}$ AND SHAIDA FARIZA SULAIMAN ${ }^{b}$ \\ ${ }^{a}$ Department of Biological Sciences, Al Al-Bayt University, 25113 Al Mafraq, Jordan. \\ ${ }^{b}$ School of Biological Sciences, Universiti Sains Malaysia, 11800 USM Pulau Pinang, Malaysia.
}

\begin{abstract}
This investigation aimed to evaluate the phytochemical constituents, antioxidant, antibacterial and $\alpha$-glucosidase inhibitory activities of $A$. tomentos $a$ essential oil. The essential oil extracted using steam distillation method possessed antibacterial activity for all tested bacteria. Comparing to cefaclor the percentage of relative inhibition zone diameter (RIZD) was $100.30 \pm 4.73 \%$ for Staphylococcus aureus and ranged between $79.67 \pm 3.79 \%$ and $84.33 \pm 4.16 \%$ for other bacteria. The essential oil showed considerable antioxidant activity using 1,1-diphenyl-2-picrylhydrazyl (DPPH) free radical scavenging activity, ferric reducing antioxidant power (FRAP) assay and metal chelating methods, the EC50 of the essential oil were $72.06 \pm 3.99,54.69 \pm 4.69$ and $50.39 \pm 2.86 \mu \mathrm{g} / \mathrm{ml} \mathrm{respectively}$, comparing $7.34 \pm$ $2.43,10.87 \pm 3.34$ and $14.50 \pm 3.46 \mu \mathrm{g} / \mathrm{ml}$ for positive controls (Trolox, EDTA and Quercetin respectively). The essential oil also possessed concentration dependent $\alpha$-glucosidase inhibitory activity with EC50 $149.20 \pm 7.63 \mu \mathrm{g} / \mathrm{ml}$ comparing to acarabose EC50 $14.50 \pm 3.46 \mu \mathrm{g} / \mathrm{ml}$. Forty compounds were identified depending in retention index (RI) and mass spectra (MS) that form $96.31 \%$ of the essential oil composition. The result showed that the ratio of the identified compounds range between $0.11 \%$ and $23.72 \%$, 3-Carene (23.72\%), Limonene (12.19\%) and $\alpha$-Terpinyl acetate $(10.22 \%)$ were found to be the major components of the essential oil. $\mathrm{m}$-Cyneme $(7.11 \%)$ and Di-n-octyl phthalate $(4.50 \%)$ present in moderate quantities. The phytochemical analyzes showed that the identified compound quantitatively and qualitatively differ from the previous study that investigate the composition of A.tomentosa L. essential oil.
\end{abstract}

Keywords: Achillea tomentosa, Antioxidant, $\alpha$-glucosidase inhibitory, Antibacterial, DPPH assay, FRAP assay.

\section{INTRODUCTION}

Investigations were directed nowadays toward exploring medicinal plants for their biological activities. Medicinal plants produce verities of biologically active compounds that reported to possess antimicrobial, antioxidant ${ }^{1}$, and enzyme inhibitory activities ${ }^{2}$. Jordan has amazing plants biodiversity profile with 2,543 species belong to 868 genera and 142 families from which 363 species belonging to 263 genera and 86 families have been recorded as medicinal plants used in traditional medicine and pharmaceuticals industry ${ }^{3}$.

Chemically synthesis antioxidants such as Butylated hydroxyanisole (BHA), tert-Butylhydroquinone (TBHQ) and Butylated hydroxytoluene (BHT) are widely used in food production to reduce lipid peroxidation. Even though these compounds are more economically than natural product they have different side effect ${ }^{4}$. In addition, the resistant of some bacteria and fungi to some common antibiotics and antimicrobial synthetic agents have been increased ${ }^{5}$. Naturally occurring plant products have gained much important because they showed a wide range of activities such as antimicrobial, antimutagenic, antioxidant and anti-inflammatory activities ${ }^{6}$. Moreover, the essential oils mode of antimicrobial action targets multiple sites that cause reduction in the development of microbial resistance $^{7}$.

The species of the genus Achillea are well known aromatic medicinal plants that used traditionally for the treatment of variety of disease in different cultures. Nowadays, several Achillea species are grown commercially and used as source for the production of biologically active substances such as anti-inflammatory, spasmolytic, choleretic, treatment of wounds ${ }^{8}$, essential oils and their constituents ${ }^{9}$. The infusion of $A$. tomentosa $\mathrm{L}$. traditionally used in Jordan as carminative, muscular relaxant of uterus and arteries, for the treatment of intestinal colic ${ }^{10}$ and stomachache ${ }^{11}$.

The essential oil of $A$. tomentosa $\mathrm{L}$. has been reported to have verities of biologically active compounds such 1,8-Cineol, $\alpha$-pinene, linalool, $\alpha$-terpineol, $\beta$-pinene and terpinen-4-ol ${ }^{12,13}$. Previous studies reported the anticancer ${ }^{14}$, enzyme inhibitory ${ }^{15}$, immunomodulatory ${ }^{16}$, antimicrobial ${ }^{17}$ antioxidant ${ }^{18,19}$ cytotoxic ${ }^{20}$ and antiinflamatory ${ }^{21}$ activities of the essential oils of Achililea spp other than A. tomentosa $\mathrm{L}$. To the best of our knowledge there is no comprehensive study was conducted to investigate the biological activity of the essential oil of $A$. tomentosa $\mathrm{L}$. Therefore, the aim of this study was to investigate the phytochemical constituents, antimicrobial, antioxidant, and the enzyme inhibition activity of essential oil of $A$. tomentosa $\mathrm{L}$. in Jordan.

\section{MATERIALS AND METHODS}

\subsection{Plant Material}

The aerial parts of wild A. tomentosa plant were collected in May 2017 at the bloom stage from Irbid $\left(32^{\circ} 30^{\prime} 11.6^{\prime \prime} \mathrm{N} 35^{\circ} 56^{\prime} 10.1 " \mathrm{E}\right)$, Jordan. The plant sample was identified by plant taxonomist and voucher specimen was deposited in the Ibn Albitar herbarium, Faculty of Sciences, Al Al-Bayt University.

\subsection{Essential oil Extraction}

The essential oil was extracted by steam distillation method for $3 \mathrm{~h}$. After distillation, the collected oil was separated from the water using separatory funnel and dried over sodium sulfate (water free) then stored at $4^{\circ} \mathrm{C}$ for further analysis ${ }^{17}$.

\subsection{Antibacterial Activity}

Antimicrobial assay of A. tomentosa essential oil was carried out according to agar well diffusion method ${ }^{22}$. The activity was evaluated against two gram positive bacterial strains (Bacillus subtilis and Staphylococcus aureus); two gram negative bacterial strain (Escherichiacoli and Pseudomonas aeruginosa). The essential oil was prepared in $10 \%$ (v:v) dilution in dimethylsulphoxide (DMSO) which was also used as negative control. The active bacterial suspension was spread over the surface of Muller-Hinton medium using a sterile cotton swab to ensure the uniform growth of the organism. Using a sterile cork borer of $8 \mathrm{~mm}$ diameter, wells were made in each agar plate. Each agar well was filled with $100 \mu \mathrm{L}$ of the diluted essential oil, DMSO was used as a negative control in the same procedure.

The plates were left for $30 \mathrm{~min}$ at room temperature to allow the diffusion of essential oil and then plates were incubated at $37^{\circ} \mathrm{C}$ for $24 \mathrm{~h}$. The zones of inhibition diameters were measured and recorded. Cefaclor $(5 \mathrm{mg} / \mathrm{ml})$ was used as standard control. Each test was performed in three replicates. The antibacterial activity was calculated by applying the following equation ${ }^{22}$ :

$$
\% \text { RIZD }=\frac{\text { IZD sample }- \text { IZD negative control }}{\text { IZD antibiotic standard }} \times 100 \%
$$

Where RIZD is the percentage of relative inhibition zone diameter and IZD is the inhibition zone diameter $(\mathrm{mm})$. 


\section{4. $\alpha$-Glucosidase Inhibitory Assay.}

The $\alpha$-glucosidase inhibitory activity was determined according to the method of Ooi et al. ${ }^{23}$ The essential oil $(25 \mu \mathrm{L})$ was mixed with $25 \mu \mathrm{L}$ of 0.1 M sodium phosphate buffer (pH 7), $25 \mu \mathrm{L}$ of $15 \mathrm{mM} \mathrm{PNPG}$, and $25 \mu \mathrm{L}$ of $\alpha$-glucosidase enzyme solution $(5 \mathrm{U} / \mathrm{mL})$. The mixture was then incubated for $40 \mathrm{~min}$ at $37^{\circ} \mathrm{C}$. One hundred microliters of $0.2 \mathrm{M}$ sodium carbonate solution was added to terminate the reaction. Acarbose was used as a positive control and the mixture without the essential oilwas used as negative control. The increase in absorbance due to hydrolysis of PNPG by $\alpha$-glucosidase was measured using a Multiskan EX microplate reader (Thermo Fisher Scientific, Finland). The inhibition percentage was calculated as follows: $\% \alpha$-glucosidase inhibition $=[$ (absorbance of negative control - absorbance of extract)/absorbance of negative control] $\times$ $100 \%$. All measurements were done in triplicate.

\subsection{Antioxidant activity}

The antioxidant activities of the essential oil were evaluated using DPPH Free Radical Scavenging, Ferric reducing antioxidant power (FRAP) assay and chelating power assay as mentioned below:

\subsubsection{DPPH Free Radical Scavenging Assay.}

Free radical scavenging activity of the essential oils was measured using the method described by Sulaiman et al. ${ }^{24}$. The reaction mixture in each well of the 96-well plate used consisted of $50 \mu \mathrm{L}$ of diluted (10\% in DMSO) essential oil was serially diluted using $150 \mu \mathrm{L}$ of $300 \mu \mathrm{M}$ DPPH ethanolic solution to get 9.77 $-1250 \mu \mathrm{g} / \mathrm{ml}$ essential oil concentration. The plates were wrapped and incubated at $37{ }^{\circ} \mathrm{C}$ for $30 \mathrm{~min}$. The decrease in absorbance was measured at $515 \mathrm{~nm}$ using a Multiskan EX microplate reader (Thermo Fisher Scientific, Finland). Trolox was used as a reference for this assay. A standard curve was obtained using different concentrations of Trolox (from 9.77 to $1250 \mu \mathrm{g} / \mathrm{ml}$ ). The absorbance of the reaction sample was compared to that of the Trolox standard curve.

EC50 value represents the effective concentration that could scaving 50\% of $\mathrm{DPPH}$, it derived from a nonlinear sigmoidal dose-response curve (GraphPadPrism 8, USA). All experiments were performed in triplicate.

\subsubsection{Ferric reducing antioxidant power (FRAP) assay}

Reducing power of the essential oil was evaluated according to the method of Ooi et al. ${ }^{23}$. Using 96-well microplate, $50 \mu$ of the diluted essential oil (10\% in DMSO) was serially diluted to get $9.77-1250 \mu \mathrm{g} / \mathrm{ml}$ essential oil concentrations using FRAP solution (10 ml of acetate buffer $300 \mathrm{mM}$ (pH of 3.6), $1 \mathrm{ml}$ of ferric chloride hexahydrate $20 \mathrm{mM}$ (in distilled water) and $1.0 \mathrm{ml}$ of TPTZ $10 \mathrm{mM}$ (dissolved in $40 \mathrm{mM} \mathrm{HCl}$ ). The solution temperature was raised to $37{ }^{\circ} \mathrm{C}$. After 20 min of incubation the increase in absorbance at $593 \mathrm{~nm}$ was measured using Multiskan EX microplate reader (Thermo Fisher Scientific, Finland). The negative control was prepared similar to the essential oil by using DMSO instead of the essential oil. Trolox was used as a positive control. The FRAP percentage was calculated using the following equation:

$\%$ ferric reducing $=$ [absorbance of essential oil $/$ maximum absorbance (3.0)] $\times 100 \%$. EC50 value represents the effective concentration that could reduce $50 \%$ of ferric $(\mathrm{Fe}+3)$ to ferrous $(\mathrm{Fe}+2)$ ions, it derived from a nonlinear sigmoidal dose-response, curve (GraphPadPrism 8, USA). All experiments were performed in triplicate).

\subsubsection{Chelating Power Assay.}

The chelating power activity was conducted according to the method of Ooi et al. ${ }^{23}$. $50 \mu \mathrm{L}$ of the diluted essential oil ( $10 \%$ DMSO) was serially diluted to get concentrations mentioned previously using $5 \mu \mathrm{L}$ of $2.0 \mathrm{mM}$ ferrous chloride hexahydrate and $130 \mu \mathrm{L}$ of methanol in a 96-well plate. The reaction was initiated by the addition of $15 \mu \mathrm{L}$ of ferrozine $(5.0 \mathrm{mM})$. The plate was incubated $10 \mathrm{~min}$ at room temperature, then the absorbance was measured at $562 \mathrm{~nm}$ using a Multiskan EX microplate reader (Thermo Fisher Scientific, Finland). The chelating power activity (\%) was calculated according to the following equation: chelating power activity $(\%)=[($ absorbance of negative control - absorbance of essential oil)/absorbance of negative control] $\times 100 \%$. EC50 value, the concentration that chelate $50 \%$ of ferrous $\left(\mathrm{Fe}^{+2}\right)$ ions, it was derived from a nonlinear sigmoidal dose response curve (GraphPadPrism 8, San Diego, CA, USA).
2.5.4. Gas Chromatography Coupled with Mass Spectrometry Analysis (GC-MS)

The identification of different chemical compounds was realised by gas phase chromatography (TRACE GC-ULTRA, S/N 20062969, Thermo-Fischer) coupled with mass spectrometry (PolarisQ, S/N 210729, Thermo Fischer) (GC/MS). The utilized column was Varian capillary column Test Report CP 7770 (CP-SIL- 5 CB; 50m length, $0.32 \mathrm{~mm}$ of Inside diameter, $0.45 \mathrm{~mm}$ Outside diameter and Film thickness $1.20 \mu \mathrm{m})$. The column temperature was programmed from 40 to $260^{\circ} \mathrm{C}$ for $5^{\circ} \mathrm{C} / \mathrm{min}$. The temperature of the injector was fixed to $250^{\circ} \mathrm{C}$ and the one of the detector (PolarisQ) to $200^{\circ} \mathrm{C}$.

Ionisation of the sample components was performed in electron impact mode (EI, $70 \mathrm{eV}$ ). The debit of gas vector (Helium) was fixed to $1 \mathrm{ml} / \mathrm{min}$. Transfer line temperature was $300^{\circ} \mathrm{C}$. The mass range from 40 to $650 \mathrm{amu}$ was scanned at a rate of $2.9 \mathrm{scans} / \mathrm{s}$. The volume of injected specimen was of $1 \mu \mathrm{l}$ of diluted oil in hexane solution $(10 \%)$. The constituents of essential oils were identified in comparison with their retention indices, calculated in relation to the retention time of a series of linear alkanes (C4- C28) with those of reference products and in comparison with their spectra of mass with those gathered in a library (NISTMS Search Version 2.0) and with those reported in the literature ${ }^{17}$.

\section{RESULT AND DISCUSSION}

Antibacterial activity of $A$. tomentosa essential oil was tested against two gram positive and two gram negative bacterial species in vitro (Figure1). Grampositive bacteria were more sensitive to the essential oil than Gram-negative bacteria. $S$. aureus was the most susceptible bacteria to $A$. tomentosa essential oil with RIZD $103 \pm 4.73 \%$, while $E$. coli was the least susceptible bacteria with RIZD $79.67 \pm 3.79 \%$. The essential oil of $A$. tomentosa was reported to contain varieties of compound such as 1,8-Cineol, germacrene-D, camphor and sabinene ${ }^{12,13}$ which was found to have bacteriocidal activity ${ }^{25}$.

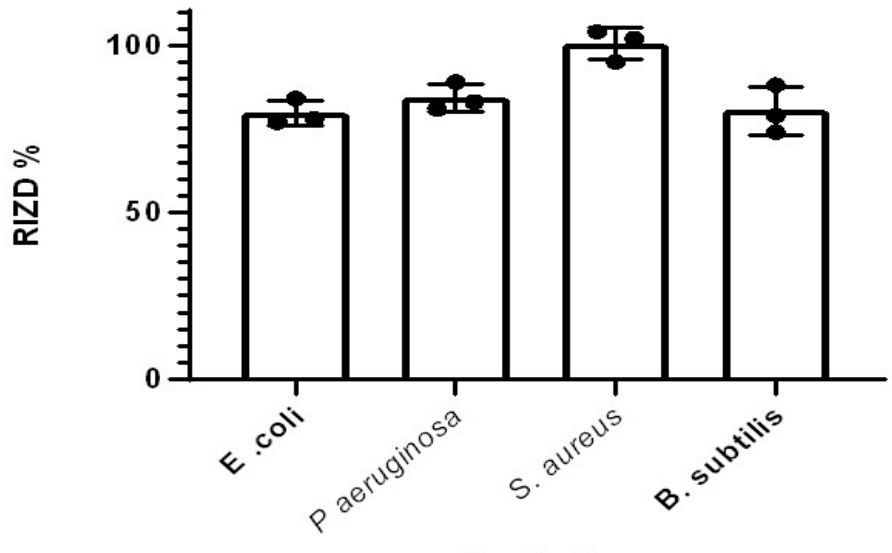

\section{Bacteria}

Figure 1. Antibacterial activity (RIZD \%) of A. tomentosa essential oil comparing to the positive controls (Cefaclor $5 \mathrm{mg} / \mathrm{ml}$ ). Values represented mean \pm SD of triplicate analyses.

Using single antioxidant evaluation method did not give the complete picture about the antioxidant properties the essential oils ${ }^{26}$. Therefore, to evaluate the antioxidant activity of the essential oil DPPH, metal chelating, and FRAP methods were used. The purple colored DPPH compound act as electron acceptor and reduced to yellow colored diphenyl picrylhydrazine. Fig. 2A showed the DPPH radical scavenging activity of the essential oil of $A$. tomentosa essential oil and the positive control quercetin. The scavenging activity of the essential oil increased with concentration with EC $72.06 \pm 3.99 \mu \mathrm{g} / \mathrm{ml}$ comparing to 7.34 $\pm 2.43 \mu \mathrm{g} / \mathrm{ml}$ for quercetin (table 1).

The ability of the essential oil to reduce ferric ion to ferrous ion (Fig. 2B) was tested using the FRAP method. The antioxidant properties of the essential oil convert ferric tripyridyltriazine complex to blue colored ferrous tripyridyltriazine at low $\mathrm{pH}$ at concentration dependent manner. The essential oil possessed lower ferric reducing activity (EC $54.69 \pm 4.69 \mu \mathrm{g} / \mathrm{ml}$ ) comparing to trolox $(10.87 \pm$ $3.34 \mu \mathrm{g} / \mathrm{ml}$ ) (table 1). The reduction effect was found to be dose dependent and reach more than $85 \%$ inhibition at high concentrations. 
Table 1. EC50* values of essential oil and the positive controls (trolox, EDTA, quercetin and Acarabose) in different inhibitory assays.

\begin{tabular}{|l|l|c|}
\hline \multirow{2}{*}{ Assay } & Tested material & EC50 Value $(\boldsymbol{\mu g} / \mathbf{m l})$ \\
\hline \multirow{2}{*}{ FRAP scavenging } & Essential Oil & $72.06 \pm 3.99$ \\
\cline { 2 - 3 } & Trolox & $7.34 \pm 2.43$ \\
\hline \multirow{2}{*}{ Metal chelating } & Essential Oil & $54.69 \pm 4.69$ \\
\cline { 2 - 3 } & EDTA & $10.87 \pm 3.34$ \\
\hline \multirow{2}{*}{-Glucosidase inhibition } & Essential Oil & $50.39 \pm 2.86$ \\
\cline { 2 - 3 } & Quercetin & $14.50 \pm 3.46$ \\
\cline { 2 - 3 } & Essential Oil & $149.20 \pm 7.63$ \\
\cline { 2 - 3 } & Acarabose & $14.50 \pm 3.46$ \\
\hline
\end{tabular}

*EC50 values $\pm \mathrm{SD}(\mu \mathrm{g} / \mathrm{ml})$ were derived from the dose-response curve (variable) of triplicate analyses.

The result of the metal chelating properties of $A$. tomentosa essential oil is shown in Fig. 2C. These properties are based on the ability of essential oil to capture $\mathrm{Fe}^{+2}$ and disrupt the formation of intense red purplish in colored $\mathrm{Fe}^{+2}$ ferrozine complex. The essential oil was found to disrupt the formation of $\mathrm{Fe}^{+2}-$ ferrozine complex in dose dependent manner with EC $50.39 \pm 2.86 \mu \mathrm{g} / \mathrm{ml}$ comparing $14.50 \pm 3.46 \mu \mathrm{g} / \mathrm{ml}$ for EDTA (table 1).

It has been reported that the antioxidant activity of essential oils related to the phytochemical composition of the oil that contain varieties of flavinoids and

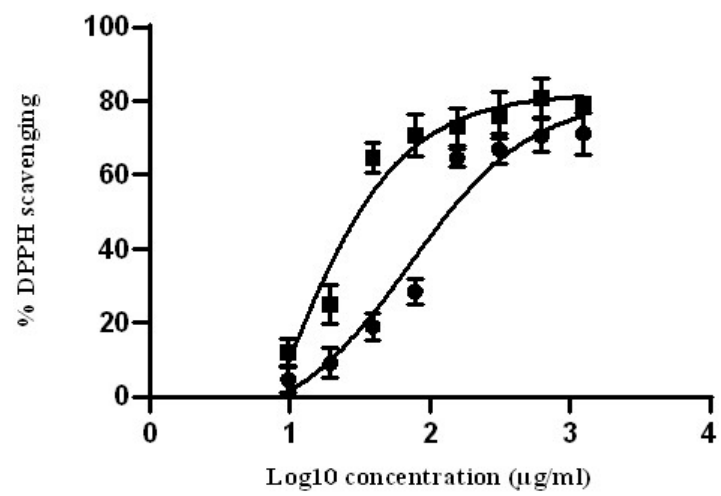

$\rightarrow$ Essential Oil

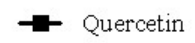

A

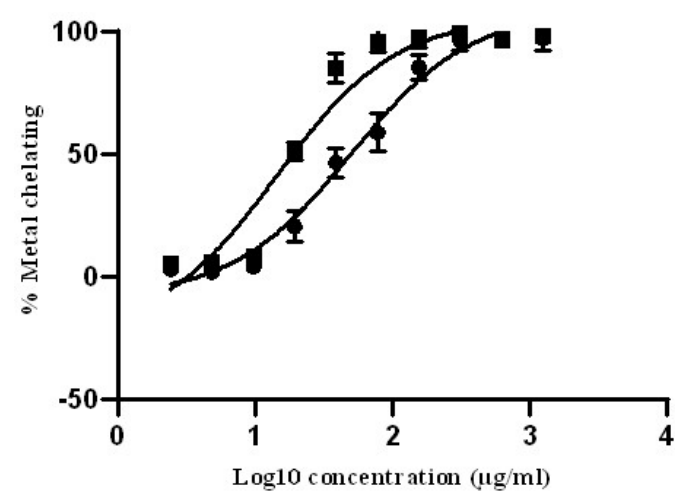

EDTA

Essential Oil phenols, in addition to the synergistic effect of the constituents ${ }^{27}, A$. tomentosa essential oil was found to contains varities of compound that belong to flavinoids and phenols ${ }^{12,13}$. Carocho and Ferreira ${ }^{28}$ also reported that plant flavonoids may promote antioxidant activities via acting as reducing agents, hydrogen donors, metals chelating and/or free radicals scavenging.

The $\alpha$-glucosidase inhibitory activity (Fig. 2D) is a preliminary approach for the development of medicines in treating type 2 diabetes mellitus. This assay measured the reduction of 4-nitrophenol from PNPG. In this assay, essential oil possessed $\alpha$-glycosidase inhibitory effects in concentration dependent manner with more than $55 \%$ of inhibition at high concentrations. The EC50 was found to be more than eight fold higher than acarbose, $149.20 \pm 7.63 \mu \mathrm{g} / \mathrm{ml}$ comparing to $17.35 \pm 3.57 \mu \mathrm{g} / \mathrm{ml}$ for acarbose (table 1). Antihyperglycemic drugs like $\alpha$ glucosidase inhibitors (acarbose) that are often administered to type II diabetic patients before a meal to control postprandial glucose levels are effective to prolong the digestion of carbohydrates and cause the delay in glucose absorption into bloodstream ${ }^{29}$.

The essential oil of A. tomentosa L. aerial parts collected form Irbid (Jordan) was extracted using steam distillation method, the yield of the oil was $0.93 \%$. The phytochemical composition of the A. tomentosa L. essential oil analyzed by GC-MS and identified by comparing mass spectra of the essential oil with the Wiley library, or with the published mass spectra is showed in table (2) A total of 40 compound were identified representing $96.31 \%$ of the essential oil. The result showed 3-Carene (2372\%), Limonene (12.19\%) and $\alpha$-Terpinyl acetate $(10.22 \%)$ were found to be the main constituents of the essential oil. The identified compound qualitatively and quantitatively differ from the result of the only single study conducted by Chizzola ${ }^{30}$ in which 1,8-cineol (eucalyptol) (56.1 $\%$ ) and $\alpha$-pinene (15.3\%) were main component of A. tomentosa L. essential oil.
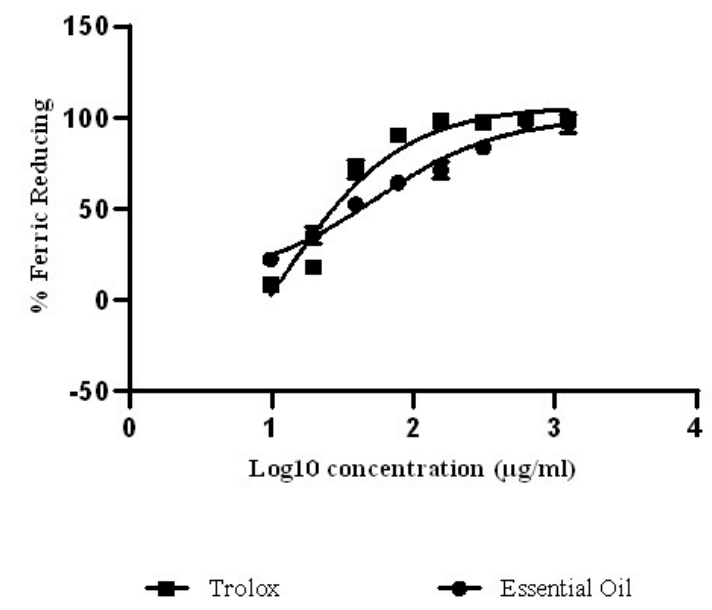

B

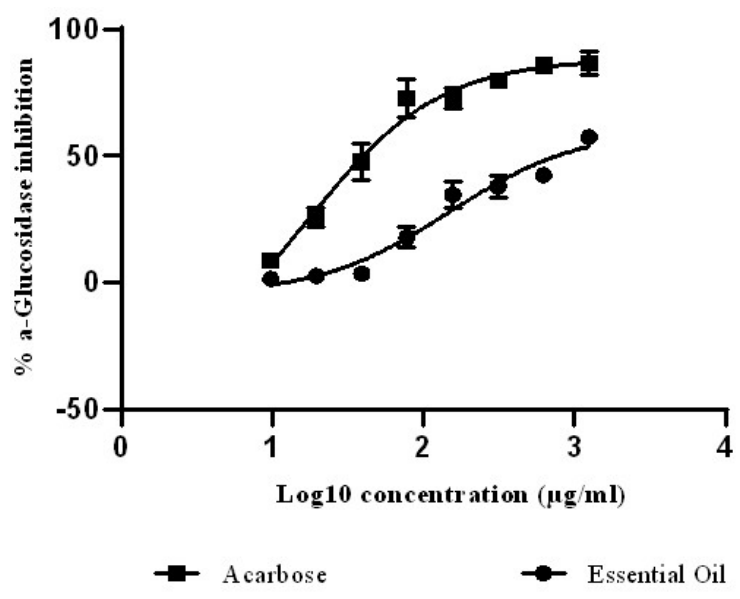

D

Figure 2. (A) DPPH scavenging, (B) ferric reducing, (C) metal chelating and (D) - $\% \alpha$-Glucosidase inhibition activities $A$. tomentosa essential oil and the positive controls (Trolox, EDTA, Quercetin and Acarabose). Values represented mean \pm SD of triplicate analyses. 
Other compound such m-Cymene (6.65\%), Di-n-octyl phthalate (4.83\%), $\alpha$ Pinene (4.56\%) and 1,8-Cineol (3.55\%) present in moderate quantities, which also varies from the study of Chizzola ${ }^{30}$ in which Linalool (4.7\%), $\alpha$-terpineol $(3.3 \%), \beta$-pinene $(2.4 \%)$ and terpinen-4-ol $(2.3 \%)$ were present in moderate quantities. As mentioned by previous studies different factors such as animal activity, harvesting time, temperature, developmental stage, geography, and growth conditions can cause quantitative and qualitative variations in the chemical constituents of essential oil ${ }^{30-34}$.

Comparing to closely related species Achillea millefolium several studies were reported that some chemotypes have sabinene, camphor, linalool, 1,8-cineole, $\beta$ pinene, or ascaridol as main essential oil components, chamazulene have been reported as major constituent in the essential oil of other chemotypse with high proportions of $\beta$-caryophyllene or nerolidol in their oils ${ }^{36-38}$.

The structure-types and individual compounds of the essential oils appeared to be valuable markers for chemotaxonomic investigations in the view of evolutionary relationships while the level of oxygenation is mainly determined by environmental factors that affect the plant growth ${ }^{39}$. Furthermore, essential oil phytochemicals belong to majority of the terpene family, thousands of phytochmical consituentes of essential oils belonging this family have so far been identified ${ }^{40}$.

To the best of our knowledge, this is the first study that reports the antibacterial, antioxidant and enzyme inhibition activity of A. tomentosa essential oil. Many investigations were conducted to evaluate the biological activity of Achillea spp. other than A. tomentosa. Al-jaber et al. ${ }^{35}$ reported that the essential oil of Achillea fragrantissima inhibit the activity of cholinesterase with IC50 $0.05 \pm 0.01 \mu \mathrm{g} / \mu \mathrm{L}$. The essential oil of Achillea millefolium L. was reported to possess strong antioxidant activities and showed bacterial inhibitory effect ${ }^{38}$. On other hand, Kazemi ${ }^{25}$ reported that the essential oil of Achillea wilhelmsii showed appreciable antioxidant activity using DPPH assay.

Table 2. Phytochmical composition of the essential oil of $A$. tomentosa $\mathrm{L}$.

\begin{tabular}{|c|c|c|}
\hline Compound & RI & $\%$ \\
\hline$\alpha$-Thujene & 933 & 0.46 \\
\hline$\alpha$-Pinene & 941 & 4.56 \\
\hline Camphene & 953 & 0.72 \\
\hline$\beta$-Thujene & 964 & 1.24 \\
\hline Thuja-2,4(10)-diene & 968 & 2.98 \\
\hline 3-Carene & 1012 & 27.93 \\
\hline m-Cymene & 1019 & 6.65 \\
\hline 1,8-Cineol & 1029 & 3.55 \\
\hline$\gamma$-Terpinene & 1052 & 2.52 \\
\hline 2-Nonanone & 1074 & 2.25 \\
\hline Linalool & 1102 & 0.59 \\
\hline $\mathrm{n}$-Amyl isovalerate & 1107 & 0.17 \\
\hline Cosmene & 1113 & 0.28 \\
\hline$\beta$-Thujone & 1118 & 1 \\
\hline Amylisovalerate & 1120 & 0.24 \\
\hline cis- $\beta$-terpineol & 1125 & 0.71 \\
\hline Camphor & 1137 & 2.38 \\
\hline Lavandulol & 1157 & 0.39 \\
\hline 2,3-Dehydro-1,8-cineole & 1161 & 0.16 \\
\hline Terpinen-4-ol & 1165 & 1.45 \\
\hline cis-Piperitol & 1185 & 0.62 \\
\hline$\alpha$-Terpineol & 1194 & 0.67 \\
\hline Myrtenol & 1201 & 0.13 \\
\hline Limonene & 1214 & 11.79 \\
\hline
\end{tabular}

\begin{tabular}{|l|c|c|}
\hline (Z)-Chrysanthenyl acetate & 1255 & 1.95 \\
\hline Lavendulyl acetate & 1273 & 0.65 \\
\hline L-Bornyl acetate & 1283 & 1.24 \\
\hline$\alpha$-Terpinyl acetate & 1351 & 9.78 \\
\hline Cyclosativene & 1373 & 0.28 \\
\hline$\alpha$-Copaene & 1389 & 0.97 \\
\hline$\beta$-Caryophyllene & 1425 & 0.35 \\
\hline$\alpha$-Humulene & 1457 & 0.18 \\
\hline 4,11 -Selinadiene & 1472 & 0.18 \\
\hline a-Selinene & 1487 & 2.51 \\
\hline Bicyclogermacrene & 1498 & 0.22 \\
\hline$\beta$-Sesquiphellandrene & 1520 & 0.07 \\
\hline (E)-Nerolidol & 1534 & 0.73 \\
\hline Germacrene B & 1559 & 0.19 \\
\hline Spathulenol & 1583 & 0.25 \\
\hline Caryophyllene oxide & 1595 & 0.13 \\
\hline c-Eudesmol, 10-epi- & 1617 & 0.21 \\
\hline$\beta$-Eudesmol & 1637 & 0.15 \\
\hline Isophytol & 1949 & 0.1 \\
\hline Phytol & 2115 & 0.34 \\
\hline Di-n-octyl phthalate & 2681 & 4.83 \\
\hline Total & & 98.75 \\
\hline
\end{tabular}

\section{CONCLUSION}

The findings of this research show that the essential oil of $A$. tomnentosa showed considerable antioxidant, antibacterial and enzyme inhibition activities. These findings may have important medical benefits and could direct attention for $A$. tomentosa plant as source for cancer and diabetes prevention and treatment compounds.

\section{DECLARATION OF COMPETING INTEREST}

The authors declare that they have no known competing financial interests or personal relationships that could have appeared to influence the work reported in this paper.

\section{ACKNOWLEDGEMENTS}

The authors extend their appreciation to Al Al-Bayt University (Jordan) and Universiti Sains Malaysia for supporting this research. Also we gratefully thank Dr. Kheng Leong Ooi (universiti sains Malaysia) and Mr. wasfi albekerat (Al AlBayt University) for their valuable help during conducting this research.

\section{REFERENCES}

1. Trumbeckaite, S., Benetis, R., Bumblauskiene, L., Burdulis, D., Janulis, V., Toleikis, A., \& Jakštas, V. Food Chemistry, 127(4), 1540-1548, (2011). doi:10.1016/j.foodchem.2011.02.014.

2. Wang, Z., Hwang, S. H., Guillen Quispe, Y. N., Gonzales Arce, P. H., \& Lim, S. S. Food Chemistry, 231, 222-230, (2017). doi:10.1016/j.foodchem.2017.03.107.

3. Oran, S. A. and \& Al-Eisawi D. M., Dirasat, Medical and Biology Sciences, 25, 84-112, (1998).

4. Chang, S. h., Bassiri, A., \& Jalali, H. Journal of Chemical Health Risks.; 3 (2):53-61, (2013). DOI: 10.22034/JCHR.2018.544031

5. Bajpai, V. K., Rahman, A., \& Kang, S. C. Int. Journal of Food Microbiology, 125, 117-122, (2008).

6. Li C. Y., Kim, H. W., Li, H., Lee, D. C, \& Rhee, H. I. Food Chemistry. 2013; 152: 592-596, (2014). doi: 10.1016/j.foodchem.2013.11.152. Epub 2013 Dec 1.

7. Koul, O., Walia, S., \& Dhaliwal, G. S. Biopest Int. 4:63-84, (2008).

8. Benedek, B., Kopp, B., \& Melizg, M. F. Journal of Ethnopharmacol; 113: 312-317, (2007). https://doi.org/10.1016/j.jep.2007.06.014 
9. Špinarová, Š., \& Petř́íková, K., 30 (1): 7-13, (2003).

10. Al-Qura'n, S. Journal of Natural Products, 1, 10-26, (2008).

11. Al-Qura'n, S. Journal of Ethnopharmacology, 123, 45-50, (2009).

12. Chizzola, R. , Journal of Essential Oil Bearing Plants, 21:2, 535-539, (2018). DOI: $10.1080 / 0972060 X .2017 .1418682$

13. Alsohaili S. International Journal of Advanced Biotechnology and Research. 19(4):238-242, (2018b).

14. Choucry, M. A. Journal of Pharmacognosy and Phytotherapy. 9(1):1-5, (2017). DOI: 10.5897/JPP2015.0399

15. Al-Jaber, H. I., Abu Zarga, M. H., Al-Aboudi, A. F., Al-Qudah, M. A., Al-Shawabkeh. A. F., Abaza I. F., Abuaisheh, M. N. \& Afifi F. U. , Journal of Herbs, Spices \& Medicinal Plants, 24(3), 272-28, (2018). https://doi.org/10.1080/10496475.2018.1463933

16. Saeidnia, S., Yassa, N., \& Rezaeipoor, R. Comparative investigation of the essential oils of $A$ talagonica Boiss and $A$ millefolium $\mathrm{L}$, Chemical composition and immunological studies. Journal of Essential Oil Research, 16: 262-264, (2004).

17. Alsohaili, S. Journal of Essential Oil Bearing Plants, 21:1, 139-145, (2018a). doi.org/10.1080/0972060X.2018.1446848

18. El-Kalamouni, C., Venskutonis. P. R., Zebib, B., Meroh, O., Raynaud, C., \& Talou, T. Medicines (Basel).; 4(2): 30-39, (2017).

19. Ardestani, A., \& Yazdanparast, R. Antioxidant and free radical scavenging potential of Achillea santolina extracts. Food Chemistry, 104, 21-29, (2007). https://doi.org/10.1016/j.foodchem.2006.10.066

20. Trifunovic', S., Vajs, V., Juranic', Z., Zizak, Z., Tesevic', V., Macura, S., et al. Phytochemistry, 67, 887-893, (2006). https://doi.org/10.1016/j.phytochem.2006.02.026

21. Abdossi, V., \& Kazemi, M. International Journal of Food Properties, 19(8), 1798-1808, (2015). doi:10.1080/10942912.2015.1086787

22. Perez, C., Pauli, M. and Bazerque, P. Acta Biologiae et Medecine Experimentaalis, 15:113-115, (1990).

23. Ooi, K.L., Muhammad, T.S.T., Tan, M.L. and Sulaiman, S.F. Journal of Ethnopharmacology, 135(3), 685-695, 2011). https://doi.org/10.1016/j.jep.2011.04.001
24. Sulaiman, S. F., Ooi, K. L., \& Supriatno, L. Journal of Agricultural Food Chemistry, 61:10080-1009, (2013). dx.doi.org/10.1021/jf4031037 | J. Agric. Food Chem. XXXX, XXX, XXX-XXX

25. Kazemi M. Trakia Journal of Sciences 1, 36-40, (2015) doi:10.15547/tjs.2015.01.005

26. Huang, D., Ou, B., \& Prior, L. Journal Agricultural Food Chemistry, 53, 1841-1856, (2005). DOI:10.1021/jf030723c

27. Wagner, H., \& Ulrich-Merzenich, G. . Phytomedicine, 16(2), 97-110, (2009). doi: 10.1016/j.phymed.2008.12.018.

28. Carocho, M., \& Ferreira, I. C. Food and Chemical Toxicology, 51, 15-25, (2013). doi: 10.1016/j.fct.2012.09.021. Epub 2012 Sep 24.

29. Krentz, A. J., \& Bailey, C.J., Drugs 65, 385-411, (2005).

30. Chizzola, R. Journal of Essential Oil Bearing Plants, 21:2, 535-539,(2018). DOI: 10.1080/0972060X.2017.1418682

31. Martins, F.T., Santos, M.H., Polo, M., and Barbosa, L.C.A. Brazilian Flavour and Fragrance Journal. 22: 123-129, (2007).

32. Duschatzky, C., Bailac, P., Carrasull, A., Firpo, N. and Ponzi, M. Volatile oil of Lippia aff. Juneliana grown in San Luis, Argentina. Effect of harvesting period on the volatile oil composition. Journal of Essential Oil Research. 11: 104-106, (1999).

33. Lopes, P.N., Kato, J.M., Andrade, A.H.E., Maia, S.G.J., Yoshida, M. Phytochemistry. 46: 689-693, (1997).

34. Putievsky, E., Ravid, U., Dudai, N. Journal of Natural Products. 49: 326329, (1986).

35. Blaschek, W. Wichtl-Teedrogen und Phytopharmaka. 6th edition. Wissenschaftliche Verlagsgesellschaft, Stuttgart, pp. 432-435. (2016).

36. Raal, A., Orav, A., and Arak, E. J. Essential Oil-Bearing Plants. 15(1):231, (2012).

37. Mockute, D., Judzentiene, A. Chemija (Vilnius). 13(3): 168-173, (2002).

38. Mockute, D., Judzentiene, A. Biochem. Syst. Ecol. 31: 1033-1045, (2003).

39. Radulovic, N., Zlatkovic, B., Palic, R., Stojanovic, G. Natural Product Communications. 2(4): 453-474, (2007).

40. Modzelewska, A., Sur, S., Kumar, S.K., Khan, S.R. Curr Med Chem Anticancer Agents 5: 477-499, (2005). 